\title{
Effect of interleukins (IL-2, IL-15, IL-18) on receptors activation and cytotoxic activity of natural killer cells in breast cancer cell
}

\author{
Wahyu Widowati ${ }^{1}$, Diana K Jasaputra ${ }^{1}$, Sutiman B Sumitro ${ }^{2}$, Mochammad A Widodo ${ }^{3}$, \\ Tjandrawati Mozef ${ }^{4}$, Rizal Rizal ${ }^{5}$, Hanna Sari W Kusuma ${ }^{5}$, Dian R Laksmitawati ${ }^{6}$, \\ Harry Murti ${ }^{7}$, Indra Bachtiar ${ }^{7}$, Ahmad Faried ${ }^{8}$
}

\begin{abstract}
1. Medical Research Center, Faculty of Medicine, Maranatha Christian University, Bandung 40164, West Java, Indonesia.

2. Department of Biology, Faculty of Mathematic and Science, Brawijaya University, Malang 65145 East Java, Indonesia.

3. Pharmacology Laboratory, Faculty of Medicine, Brawijaya University, Malang 65145, East Java, Indonesia.

4. Research Center for Chemistry, Indonesian Institute of Sciences, Serpong Banten 15310, Indonesia.

5. Biomolecular and Biomedical Research Center, Aretha Medika Utama, Bandung 40163, West Java, Indonesia.

6. Faculty of Pharmacy, Pancasila University, Jagakarsa, Jakarta Selatan 12640, Indonesia.

7. Stem Cell and Cancer Institute, Jl A Yani no 2 Pulo Mas, Jakarta 13210, Indonesia.

8. Department of Neurosurgery and Stem Cell Working Group, Faculty of Medicine, Universitas Padjadjaran Dr. Hasan Sadikin Hospital, Bandung 40161, West Java, Indonesia.
\end{abstract}

\begin{abstract}
Introduction: Breast cancer is one of the leading cause of cancer deaths in women. Metastasis in BC is caused by immunosurveillance deficiency, such NK cell maturation, low NK activity and decreasing cytotoxicity. This study was performed to improve activating receptors and cytotoxicity of NK cells using interleukins (ILs).

Methods: Human recombinant IL-2, -15 , and -18 were used to induce NK cells. We measured the activating and inhibiting receptors, proliferation activity of NK cells, and the cytotoxicity of NK cells on BC cells (MCF7). The effects of ILs were tested on the NK cell receptors CD314, CD158a and CD107a with flowcytometry, proliferation at various incubation times with 3-(4,5-dimethylthiazol-2-yl)-5-(3-carboxy methoxyphenyl)-2-(4-sulfophenyl)-2H-tetrazolium (MTS) assay and concentrations of TNF- $\alpha$ and IFN- $\gamma$ by NK cells with ELISA.

Results: ILs increased NK cell receptor levels (CD314, CD158a, and CD107a) at 24 hours of incubation. ILs increased NK cell viability, which increased with longer incubation. Moreover, ILs-induced NK cells inhibited proliferation in MCF7 cells, as well as increased TNF- $\alpha$, IFN- $\gamma$, PRF1 and GzmB secretion.

Conclusion: IL-2, IL-15, and IL-18 improved activating receptors and proliferation of NK cells. IL-induced NK cells increased TNF- $\alpha$, IFN- $\gamma$, PRF1 and GzmB secretion and cytotoxic activity on BC cells. High NK cell numbers increased BC cell growth inhibition.
\end{abstract}

Keywords: Activator; breast cancer; interleukins; natural killer; receptor.

DOI: https://doi.org/10.4314/ahs.v20i2.36

Cite as: Widowati W, Jasaputra DK, Sumitro SB, Widodo MA, Mozef T, Rizal R, et al. Effect of interlenkins (IL-2, IL-15, IL-18) on receptors activation and cytotoxic activity of natural killer cells in breast cancer cell. Afri Health Sci. 2020; 20(2): 822-832. https://doi. org/10.4314/abs.v20i2.36

\section{Introduction}

Breast cancer $(\mathrm{BC})$ is the leading cause of cancer deaths in women ${ }^{1}$, accounting for approximately $43.3 \%{ }^{2}$. Mor-

\footnotetext{
Corresponding author:

Wahyu Widowati,

Medical Research Center,

Faculty of Medicine,

Maranatha Christian University,

Prof. Drg. Suria Sumantri 65, Bandung,

40164, West Java, Indonesia

Email:wahyu_w60@yahoo.com
}

tality of most patients with solid tumors is due to metastatic spread to other organs ${ }^{1}$. Metastasis occurs when tumor cells acquire invasive features ${ }^{3}$ and the ability to escape from antitumor immunity ${ }^{4,5}$. Defects in antitumor immunity may also facilitate $\mathrm{BC}$ occurrence ${ }^{6}$. Metastasis in $\mathrm{BC}$ is caused by deficient immunosurveillance, including impairment of NK cell maturation, low NK cell counts in peripheral blood mononuclear cells (PB$\mathrm{MCs}$ ), significantly lower NK activity in patients with $\mathrm{BC}$ than in healthy individuals ${ }^{7}$, decreased cytotoxic function $^{8,9}, \mathrm{NK}$ abnormalities ${ }^{8}$, poor tumor infiltrate ${ }^{10,11}$, low NK cell numbers in tumors due to their inefficient 
homing into malignant tissues ${ }^{8}$, defective expression of activating receptors such as NKG2D, NKG2C, NKp30, NKp46, CD161, CD56 dim , CD16, DNAM-1, and CD69 and high immunosuppression, namely overexpression, of inhibitory receptors CD158a, CD158b, and NK$\mathrm{G}_{2} \mathrm{~A}^{8}$. One cancer therapy is to stimulate NK cell function and combine them with other agents to boost anti-cancer activity ${ }^{12}$. NK cells as immunomodulators can be activated using interleukin into lymphokine-activated killer cells (LAK). NK cells respond to a variety of cytokines, such as IL-2, IL-12, IL-15, IL-18, IL-21, and Type I Interferons (IFNs), discretely or in combination with each other or with other modulators ${ }^{13}$, and tumor necrosis factor $(\mathrm{TNF})^{14}$, which increases their cytolytic, secretory and anti-cancer functions ${ }^{15}$. Through its interaction with NK cells, IL-2 treatment was related with favourable result in various cancer type, making it the first effective immunotherapy for human cancer ${ }^{16}$.

Immunotherapy using NK cells can be used to obtain the large and sufficient numbers of functional NK cells necessary for clinical therapy. The number, purity and state of NK cell proliferation and activation are key factors in immunotherapy ${ }^{17}$. NK cells are known as necessary effectors in suppressing cancer proliferation ${ }^{18}$. Therefore, the focus of recent cancer therapy has been to promote and develop NK cells as drugs ${ }^{9}$, using NK effectors such as cytokines ${ }^{8}$.

This study was conducted to evaluate the effect of inducing interleukins (IL-2, IL-5, and IL-18) on NK cells toward the following: i) improvement of NK cell activating receptors, including CD314, CD158d and CD107a; ii) increased proliferation of NK cells; iii) NK cell secretion of factors such as IFN- $\gamma$ and TNF- $\alpha$; iv) secretion of IFN- $\gamma$, TNF- $\alpha$, perforin (PRF1) and granzyme B (GzmB) co-cultured NK and BC cells inhibition of $\mathrm{BC}$ cell proliferation.

\section{Materials and methods \\ Induction of NK cells using interleukins (IL-2, IL- 15, IL-18)}

NK92MI cells (ATCC® CRL2408 ${ }^{\mathrm{TM}}$ ) from Aretha Medika Utama, Biomolecular and Biomedical Research Center, Bandung, Indonesia, at a density of $2 \times 10^{6} /$ well, were grown and maintained in medium containing RPMI 1640 (Gibco 22400089), 10\% FBS (Gibco 10270106), and 1\% antibiotic/antimycotic (Gibco 1772653). Cells were treated with 5 or $10 \mathrm{ng} / \mathrm{ml}$ of IL-2 (Biolegend 589106), IL-15 (Biolegend 715902) or IL-
18 (GenScript Z031189) incubated at 5\% $\mathrm{CO}_{2}, 37^{\circ} \mathrm{C}$ for $24 \mathrm{~h}$, which resulted in IL2-induced NK (IL2-NK), IL15-induced NK (IL15-NK), and IL18-induced NK (IL18-NK) cells, respectively. The IL-NK cells were used for assays such as measuring $\mathrm{NK}$ cell receptors, NK cell viability, cytotoxic activity toward BC cells by co-culture, and effector molecule secretion by NK cells (IFN $\gamma, \mathrm{TNF} \alpha$, PRF1, and GzmB levels).

\section{Detection of NK cell receptors using fluorescence activated cell sorting (FACS)}

NK92 cells with a density of $5 \times 10^{5} /$ well were cultured in complete medium containing RPMI 1640,10\% FBS, and $1 \%$ antibiotic/antimycotic incubated at $5 \% \mathrm{CO}_{2}$, $37{ }^{\circ} \mathrm{C}$ for $24 \mathrm{~h}$. The NK cells were induced with IL2, IL-15, and IL-18 (10 ng/ml) and incubated for 24 h. The medium was collected, and $1 \times 10^{5}-1 \times 10^{6} \mathrm{NK}$ cells were added to $500 \mathrm{ml}$ of FACS Buffer (PBS $+2 \%$ FBS). Furthermore, NK receptors were stained with the surface markers CD314 (Ms anti-human, Invitrogen 521927), CD107a (Ms anti-human, Invitrogen 519297), and CD158d (Ms Anti-human, Invitrogen 523653) in single and multiple staining, followed by incubation in a dark room at $4{ }^{\circ} \mathrm{C}$ for $30 \mathrm{~min}$. The cells were washed twice using FACS Buffer. NK receptors were stained with CD314, CD158d, or CD107a antibody conjugated with PE. The receptors were analyzed by flow cytometry with a MACSQuant ${ }^{\circledR}$ Analyzer. The experiments and measurement of surface markers were performed in triplicate ${ }^{19,20}$.

\section{Cell viability of ILs-induced NK (ILs-NK)}

The NK cells at a density of $1 \times 10^{4} /$ well were grown in 96-well plates in NK medium. The cells were induced directly with 5 or $10 \mathrm{ng} / \mathrm{ml}$ of IL-2, IL-15, or IL-18 daily. Furthermore, cells were incubated at $5 \% \mathrm{CO}_{2}$ and $37^{\circ} \mathrm{C}$, in a humidified atmosphere for $24,48,72$, or 96 $\mathrm{h}^{20}$. To determine the those above IL-NK viability per day, cell viability was assayed based on an optimized reagent containing resazurin converted to fluorescent resorufin by viable cells that absorbs light at $490 \mathrm{~nm}$ using 3-(4,5-dimethylthiazol-2-yl)-5-(3-carboxy methoxyphenyl)-2-(4-sulfophenyl)-2H-tetrazolium assay (MTS; Promega G3580) $)^{21,22}$.

\section{Effector molecules of ILs-induced NK cells}

ILs-induced NK cells at a density of $1 \times 10^{5}$ cells/well were grown and maintained in NK medium and incubated at $5 \% \mathrm{CO}_{2}, 37^{\circ} \mathrm{C}$ for $24 \mathrm{~h}$. Cells and medium were centrifuged at $500 \mathrm{~g}$ for $4 \mathrm{~min}$, and the culture 
supernatant was preserved at $-80^{\circ} \mathrm{C}$ for subsequent assays, such as for IFN- $\gamma$ and TNF- $\alpha^{22,23}$. IFN- $\gamma$ secretion from NK cells was measured using a commercial enzyme-linked immunosorbent assay kit (Human ELISA KIT, Biolegend 430104) and the TNF $\alpha$ secretion from NK cells using a human ELISA Kit (Human ELISA KIT, Biolegend 430104) following the manufacturer's recommendation.

Co-culture of ILs-NK and breast cancer cells for measuring the cytoplasmic granules and effector molecules

The NK cells were treated with 5 or $10 \mathrm{ng} / \mathrm{ml}$ of IL-2, IL-15, or IL-18 incubated at $5 \% \mathrm{CO}_{2}, 37^{\circ} \mathrm{C}$ for $24 \mathrm{~h}$, which resulted in IL2-induced NK (IL2-NK), IL15-induced NK (IL15-NK), and IL18-induced NK (IL18NK) cells. The MCF7 cells at a density of $1 \times 10^{6}$ cells/ well (DMEM $+20 \%$ FBS $+1 \%$ antibiotic/antimycotic) were cultured in a 24 -well plate. The cells were incubated in a humidified atmosphere with $5 \% \mathrm{CO}_{2}$ at $37^{\circ} \mathrm{C}$ for $24 \mathrm{~h}$. NK cells were adjusted to $1 \times 10^{5}$ for the ratio 1:5 (MCF7:IL2-NK = 1:5; MCF7:IL15-NK = 1:5; MCF7:IL18-NK $=1: 5$ ) and the ratio 1:1 (MCF7:IL2$\mathrm{NK}=1: 1 ;$ MCF7:IL15-NK = 1:1; MCF7:IL18-NK = 1:1 NK cells) and were resuspended in 24-well plates containing MCF7 with the NK medium and DMEM at the ratio $1: 1(50 \%: 50 \%)$ according to the optimized research (data not shown). The co-cultures of IL2-NK, IL15-NK, IL18-NK and MCF7 were incubated in a humidified atmosphere with $5 \% \mathrm{CO}_{2}$ at $37^{\circ} \mathrm{C}$ for 96 h. Cells and medium were centrifuged at $500 \mathrm{~g}$ for 4 min, and the medium was preserved at $-80^{\circ} \mathrm{C}$ for subsequent assays such as for IFN- $\gamma$ (Human ELISA KIT, Biolegend 430104), TNF- $\alpha$ (Human ELISA KIT, Biolegend 430204), PRF1 (Human ELISA KIT, ElabSci E-EL-H1123) and GzmB (Human ELISA KIT, ElabSci E-EL-H1617) ${ }^{23,24}$.

\section{Growth inbibition of ILs-NK cells on breast cancer cells}

This research method was adopted and modified based on the previous research by Parihar et al. (2002) and Lu et al. $(2008)^{22,23}$. NK cells at a density of $1 \times 10^{6} /$ well were grown and maintained in NK medium, and cells were treated with 5 and $10 \mathrm{ng} / \mathrm{ml}$ of IL-2, IL-15, or IL-18 daily and incubated at $5 \% \mathrm{CO}_{2}, 37^{\circ} \mathrm{C}$ for 96 $\mathrm{h}$, resulting in IL-induced NK cells. The BC cell line MCF7 (ATCC ${ }^{\circledR}$ HTB22 ${ }^{\mathrm{TM}}$ ) was obtained from Aretha Medika Utama Biomolecular and Biomedical Research
Center, Bandung, Indonesia, plated at a density of $1 \times 10^{4} /$ well and cultured on 96 -well plates in $100 \mu \mathrm{l}$ of complete medium (Dulbecco's Modified Eagle's Medium (DMEM high glucose; Gibco 11995065), 10\% FBS, $1 \%$ antibiotic/antimycotic) and incubated at $5 \% \mathrm{CO}_{2}$, $37^{\circ} \mathrm{C}$ for $24 \mathrm{~h}$. The following day, culture supernatant was aspirated, and the cells were washed with PBS (Invitrogen 1740576) and replaced with complete medium (DMEM $+1 \%$ antibiotic/antimycotic, 10\% FBS). Cells were incubated at $5 \% \mathrm{CO}_{2}, 37^{\circ} \mathrm{C}$ for $24 \mathrm{~h}$. For the $\mathrm{BC}$ cells treated with $\mathrm{NK}$ cells in the number-dependent experiment, the ratios of $\mathrm{BC}$ cells to IL-induced NK cells were $1: 5(10,000: 50,000), 1: 2(10,000: 20,000)$, $1: 1(10,000: 10,000)$ and $2: 1(10,000: 5,000)$. The medium comparison of cocultured cells was based on a preliminary study, and the best medium comparison of NK medium and BC medium was 1:1. The controls were the single cultures of NK92MI or MCF7. The co-cultured NK and BC cells were incubated at 5\% $\mathrm{CO}_{2}, 37^{\circ} \mathrm{C}$ for $24 \mathrm{~h}, 48 \mathrm{~h}, 76 \mathrm{~h}$, or $96 \mathrm{~h}$. To determine the growth inhibition or cytotoxic effects of NK cells toward BC cells using MTS assays, $20 \mu \mathrm{l}$ of reagent cell titer $96{ }^{\circledR}$ Aqueouse one solution assay (Promega G3580) was added to each well and incubated for 3 h. The cell absorbance was measured at $490 \mathrm{~nm}$ wavelength (Multiskan Go, Thermo Scientific. The inhibitory effect of IL-NK cells toward BC cell viability was calculated according to the following formula ${ }^{23}$ :

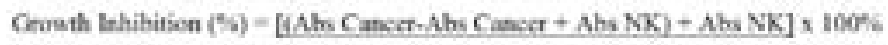

\section{Statistical analysis}

\section{Abs Cancer}

Statistical analysis was conducted using SPSS software (version 16.0). Data were presented as Mean \pm Standard Deviation. Significant differences among treatments were determined using the one-way Analysis of variance (ANOVA) and $p<0.05$ were considered as statistically significant, along with Tukey honestly significant difference post hoc test and $95 \%$ confidence interval.

\section{Results}

\section{Effect of ILs toward NK cell characteristics}

To determine the effect of human recombinant ILs toward NK receptors, we evaluated the NK receptors including CD314, CD107a and CD158d (Figures 1). The data showed that ILs (IL-2, IL-15, and IL-18) significantly up-regulated CD314 and CD107 and that IL-15 and IL-18 significantly up-regulated CD158d, but IL-2 did not significantly up-regulate CD158d. 


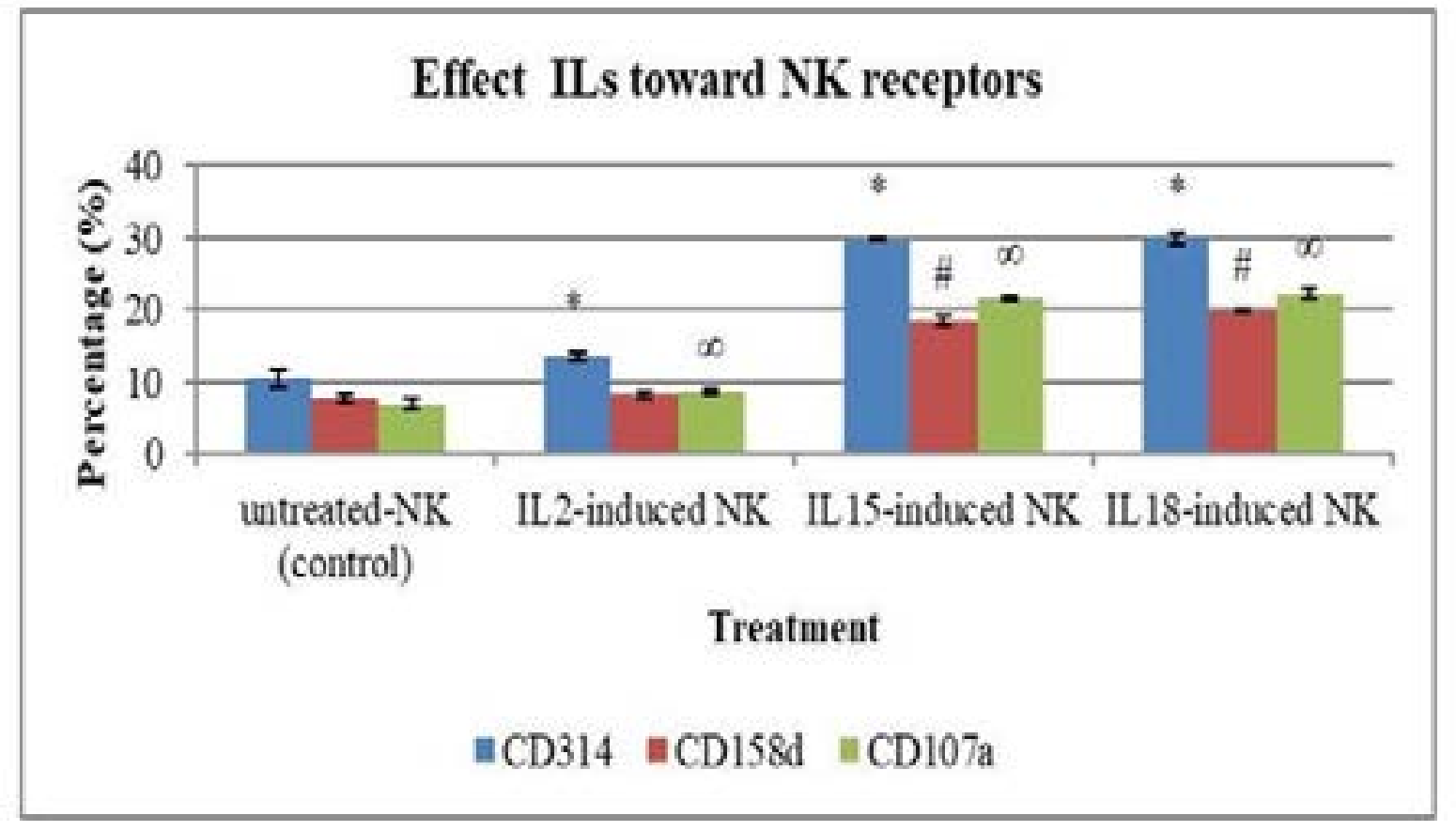

Figure 1. Effect of $10 \mathrm{ng} / \mathrm{ml}$ ILs (IL-2, IL-15, and IL-18) toward NK cell receptors (CD314, CD158d, and CD107a) for $24 \mathrm{~h}$ incubation.

\begin{abstract}
*The data are presented as histogram among treatment, this research was conducted in triplicate for each treatment, symbol *present significant differences among inducer (IL2-induced NK, IL15-induced NK, IL18-induced NK) compared to control (untreated NK cells) toward CD314 expression, symbol \# present significant differences among inducer (IL2-induced NK, IL15-induced NK, IL18-induced NK) compared to control (untreated NK cells) toward CD158d expression, symbol $\infty$ present significant differences among inducer (IL2-induced NK, IL15-induced NK, IL18-induced NK) compared to control (non-induced NK cells) toward CD107a expression.
\end{abstract}

\section{Effect of ILs toward NK cell proliferation}

NK cells require effectors to activate NK cells; thus, this study was conducted to evaluate the effect of ILs (IL-2, IL-15, and IL-18) toward NK cell numbers. We used ILs at levels of 5 and $10 \mathrm{ng} / \mathrm{ml}$, and NK cell proliferation was calculated at various incubation times $(24$, 48, 72, and $96 \mathrm{~h}$; Table 1). The data show (Table 1) that ILs (IL-2, IL-15, and IL-18) increased NK cell proliferation and that proliferation was lower at $24 \mathrm{~h}$ of incubation compared to $48 \mathrm{~h}, 72 \mathrm{~h}$, and $96 \mathrm{~h}$ of incubation.
A higher concentration $(10 \mathrm{ng} / \mathrm{ml})$ of ILs resulted in higher proliferation compared to $5 \mathrm{ng} / \mathrm{ml}$.

\section{Effect of ILs toward NK cell secretion of IFN- $\gamma$ and TNF- $\alpha$}

In this study, we evaluated the effect of $10 \mathrm{ng} / \mathrm{ml} \mathrm{ILs}$ (IL-2, IL-15, and IL-18) toward IFN- $\gamma$ and TNF- $\alpha$ secretion by NK cells for $24 \mathrm{~h}$ (Figure 2). Figure 2 shows that IL-2, IL-15, and IL-18 significantly increased IFN- $\gamma$ and TNF- $\alpha$ compared to controls (untreated NK cells). 
Table 1. Effect ILs (IL-2, IL-15, IL-18) toward NK cells viability (\%)

\begin{tabular}{|c|c|c|c|c|}
\hline \multirow{2}{*}{$\begin{array}{l}\text { Concentrations } \\
\text { (ILs) for inducing } \\
\text { NK cells }\end{array}$} & \multicolumn{4}{|c|}{ NK cells viability (\%) } \\
\hline & $\begin{array}{c}\text { Incubation time } \\
(24 \mathrm{~h})\end{array}$ & $\begin{array}{c}\text { Incubation time } \\
(48 \mathrm{~h})\end{array}$ & $\begin{array}{c}\text { Incubation time } \\
(72 \mathrm{~h})\end{array}$ & $\begin{array}{c}\text { Incubation time } \\
(96 \mathrm{~h})\end{array}$ \\
\hline $\begin{array}{c}\text { Control } \\
\text { (non-induced NK) }\end{array}$ & $100.00 \pm 13.16^{\mathrm{abA}}$ & $100.00 \pm 4.17$ abA & $100.00 \pm 0.46^{\text {aA }}$ & $100.00 \pm 6.15^{\mathrm{aA}}$ \\
\hline IL2-NK (5 ng/ml) & $104.14 \pm 12.49^{\mathrm{abA}}$ & $109.66 \pm 9.12$ aceAB & $134.50 \pm 16.67$ севс & $143.13 \pm 3.20 \mathrm{bcc}$ \\
\hline IL2-NK (10 ng/ml) & $122.67 \pm 9.36^{\mathrm{bA}}$ & $129.12 \pm 0.39^{\mathrm{cA}}$ & $152.69 \pm 11.63$ св & $153.16 \pm 4.21$ св \\
\hline IL15-NK (5 ng/ml) & $79.36 \pm 12.27 \mathrm{aA}$ & $124.92 \pm 0.72$ всв & $138.27 \pm 1.14$ сев & $141.88 \pm 9.35$ ссв \\
\hline IL15-NK (10 ng/ml) & $109.29 \pm 23.55 \mathrm{abA}$ & $134.62 \pm 5.64{ }_{\mathrm{cAB}}$ & $140.77 \pm 0.44$ всав & $153.37 \pm 1.73$ св \\
\hline IL18-NK (5 ng/ml) & $81.19 \pm 17.92^{\text {abA }}$ & $87.14 \pm 8.76^{\text {aA }}$ & $120.36 \pm 6.64$ авв & $128.88 \pm 5.53$ ьв \\
\hline IL18-NK (10 ng/ml) & $104.81 \pm 11.12^{\mathrm{abA}}$ & $115.75 \pm 21.71_{\text {вав }}^{\text {сав }}$ & $155.28 \pm 7.59 \propto$ & $142.31 \pm 7259 \mathrm{bcc}$ \\
\hline
\end{tabular}

*This research was performed 3 replication for NK cells viability. Data of NK cells viability (\%) are presented as mean \pm standard deviation, different small letters in the same column (among concentrations of ILs (IL-2, IL-15, IL-18) treatment in each periodic incubations (day 1, 2, 3, 4). Different capital letters in the same row (among periodic incubations in each ILs treatment), were significantly different at $\mathrm{p}<0.05$ (Tukey honestly significant difference post hoc test)

Effect of ILs toward IFN- $\gamma$, TNF- $\alpha$, PRF1 and GzmB in co-cultured breast cancer and NK cells

This study was aimed to measure the cytokines including IFN- $\gamma$, TNF- $\alpha$, and cytolytic enzymes such as PRF1 and GzmB, which are secreted by co-cultured MCF7 and NK cells (Table 2). The data in Table 2, show that MCF7 cells secreted low levels of PRF1 $(20.00 \mathrm{pg} / \mathrm{ml})$ and $\mathrm{GzmB}(13.33 \mathrm{pg} / \mathrm{ml})$ and produced low levels of IFN- $\gamma(1.83 \mathrm{pg} / \mathrm{ml})$ and TNF- $\alpha(1.98 \mathrm{pg} / \mathrm{ml})$. Co-cul- ture of MCF7 and non-activated NK cells increased IFN- $\gamma$, TNF- $\alpha$, PRF1, and Gzm. Higher NK cell numbers in co-cultured cells increased the cytokines and cytolytic enzyme secretion of both non-activated and activated NK cells. IL-15 and IL-18 were the best effectors to induce NK cells to secrete IFN- $\gamma$, TNF- $\alpha$, PRF1, and GzmB. The highest levels of IFN- $\gamma, \mathrm{TNF}-\alpha$, PRF1, and GzmB in co-cultured MCF7 and NK cells were secreted from co-cultured MCF7 and IL18-NK cells at a ratio of 1:5.

Table 2. Effect ILs toward cytokines, cytolitic enzyme of co-culture breast cancer and NK cells

\begin{tabular}{|c|c|c|c|c|}
\hline \multirow{2}{*}{$\begin{array}{l}\text { Samples } \\
(\mathrm{Co} \text {-culture } \mathrm{MCF} 7+\mathrm{NK}) \\
\text { in various ratio }\end{array}$} & \multicolumn{4}{|c|}{ Level of cytokines, cytolitic enzyme } \\
\hline & $\mathrm{IFN}-\gamma(\mathrm{pg} / \mathrm{ml})$ & $\begin{array}{l}\text { TNF- } \alpha \\
(\mathrm{pg} / \mathrm{ml})\end{array}$ & PRF1 (pg/ml) & $\mathrm{GzmB}(\mathrm{pg} / \mathrm{ml})$ \\
\hline Control (MCF7) & $1.83 \pm 0.33^{\text {a }}$ & $1.98 \pm 0.24^{\text {a }}$ & $20.00 \pm 10.00^{a}$ & $13.33 \pm 4.51^{\mathrm{a}}$ \\
\hline MCF7 + NK(1:1) & $14.50 \pm 3.93^{b}$ & $5.24 \pm 0.28^{\text {a }}$ & $40.00 \pm 10.00$ ab & $29.00 \pm 4.36^{b}$ \\
\hline $\mathrm{MCF} 7+\mathrm{NK}(1: 5)$ & $32.28 \pm 1.35^{\circ}$ & $13.85 \pm 2.79^{b}$ & $110.00 \pm 10.00^{b}$ & $55.67 \pm 12.50^{\circ}$ \\
\hline MCF7 + IL2-NK(1:1) & $17,39 \pm 3.56^{b}$ & $15.04 \pm 0.21 \mathrm{bc}$ & $160.00 \pm 40.00$ dd & $87.00 \pm 11.79^{\circ}$ \\
\hline MCF7 + IL2-NK (1:5) & $35.72 \pm 0.38^{c}$ & $37.44 \pm 1.47$ d & $230.00 \pm 40.00^{\mathrm{de}}$ & $149.00 \pm 7.21^{\mathrm{d}}$ \\
\hline MCF7 + IL15-NK (1:1) & $18.28 \pm 5.74^{b}$ & $19.03 \pm 1.66^{\mathrm{bc}}$ & $150.00 \pm 20.00$ dd & $88.67 \pm 11.68^{\circ}$ \\
\hline MCF7 + IL15-NK (1:5) & $59.28 \pm 1,90^{\mathrm{d}}$ & $42.21 \pm 4.23$ & $250.00 \pm 30.00^{\text {de }}$ & $140.67 \pm 12.86^{\mathrm{d}}$ \\
\hline MCF7 + IL18-NK (1:1) & $17.72 \pm 3.37^{b}$ & $20.44 \pm 2.37 \mathrm{c}$ & $170.00 \pm 40.00$ dd & $96.00 \pm 1.73$ 。 \\
\hline MCF7 + IL18-NK (1:5) & $60.17 \pm 3.71^{\mathrm{d}}$ & $60.56 \pm 3.15$ & $320.00 \pm 70.00^{\mathrm{f}}$ & $149.67 \pm 11.93$ \\
\hline
\end{tabular}

*This research was peroformed 3 replication for IFN- $\gamma$, TNF- $\alpha$, PRF1, GzmB. Data are presented as mean \pm standard deviation. Different supercript small letters $\left({ }^{(a, b, c, d}\right)$ in the same coloumn (among ratio of MCF7 and ILs-induced NK cells in IFN- $\gamma$ level), different supercript small letters $\left({ }^{\mathrm{a}, \mathrm{bcc}, \mathrm{d}, \mathrm{d}}\right)$ in the same coloumn (among ratio of MCF7 and ILs-induced NK cells in TNF- $\alpha$ level), different supercript small letters $\left({ }^{a, a b, b, c d, d e, f}\right)$ in the same coloumn (among ratio of MCF7 and ILs-induced NK cells in PFR1 level), different supercript small letters $\left({ }^{\mathrm{a}, \mathrm{b}, \mathrm{c}, \mathrm{d}}\right)$ in the same coloumn (among ratio of MCF7 and ILsinduced NK cells in GzmB level), were significantly different at $\mathrm{p}<0.05$ (Tukey honestly significant difference post hoc test). 
Effect of ILs toward BC proliferation in co-cultured $\mathrm{BC}$ and NK cells

To investigate NK cells as immunomodulators to kill and inhibit $\mathrm{BC}$ cell proliferation, we performed this research using co-cultured MCF7 and NK cells at various ratios. The effect of NK cells at various ratios can be seen in Table 3. The data in Table 3, showed that the ratio of $\mathrm{BC}$ and $\mathrm{NK}$ cells determined cancer cell proliferation, and the NK cell number affected cytotoxic potency on cancer cells. The growth inhibition among the MCF7 : NK ratio was significantly different. Higher NK cell numbers were more toxic than lower NK cell numbers, and the lowest NK cell number demonstrated the lowest growth inhibition on MCF7. The highest growth inhibition of NK cells was obtained with the highest NK numbers, with the MCF7: NK ratio of 1:5. The IL inducers (IL-2, IL-15, and IL-18) did not exhibit significant differences in the inhibition of cell proliferation.

Table 3. Effect ILs-induced NK cells and NK cells number toward breast cancer cells growth inhibition

\begin{tabular}{|c|c|c|c|c|}
\hline \multirow[b]{2}{*}{$\begin{array}{c}\text { ILs-induced NK cells } \\
\text { (ILs-NK) }\end{array}$} & \multicolumn{4}{|c|}{ Comparison breast cancer (MCF7) and NK cell } \\
\hline & $(1: 5)$ & $(1: 2)$ & $(1: 1)$ & $(2: 1)$ \\
\hline $\begin{array}{c}\text { Control } \\
\text { (non-induced NK) }\end{array}$ & $85.01 \pm 2.65$ aD & $65.16 \pm 4.21 \mathrm{ac}$ & $42.19 \pm 5.60$ ав & $16.79 \pm 1.08$ aA \\
\hline IL2-NK (5 ng/ml) & $101.42 \pm 1.26^{\mathrm{aD}}$ & $78.22 \pm 1.91 \mathrm{ac}$ & $65.02 \pm 2.23 \mathrm{aB}$ & $35.71 \pm 0.72^{\text {beA }}$ \\
\hline IL2-NK ( 10 ng/ml) & $98.79 \pm 4.20 \mathrm{aD}$ & $77.74 \pm 9.39$ ас & $58.72 \pm 1.86^{\mathrm{aв}}$ & $37.64 \pm 1.70 \mathrm{cA}$ \\
\hline IL15-NK (5 ng/ml) & $86.75 \pm 10.58 \mathrm{ac}$ & $66.22 \pm 4.10$ ав & $44.68 \pm 7.10^{\mathrm{aA}}$ & $34.65 \pm 4.75$ bca \\
\hline IL15-NK (10 ng/ml) & $86.83 \pm 13.86^{\mathrm{aC}}$ & $69.64 \pm 8.53 \mathrm{aBC}$ & $47.03 \pm 11.93$ аАв & $37.83 \pm 8.25^{\mathrm{cA}}$ \\
\hline IL18-NK (5 ng/ml) & $87.58 \pm 1.98$ ав & $77.78 \pm 4.79$ ав & $47.66 \pm 17.77$ aA & $25.28 \pm 3.28$ abA \\
\hline IL18-NK (10 ng/ml) & $86.01 \pm 1.52^{\mathrm{aD}}$ & $67.62 \pm 6.79 \mathrm{ac}$ & $52.45 \pm 1.08_{\mathrm{aB}}$ & $30.04 \pm 1.75$ beA \\
\hline
\end{tabular}

\footnotetext{
${ }^{*}$ This research was performed 3 replication. The data of cells inhibition (\%) are presented as mean \pm standard deviation, different small letters in the same column (among concentrations of ILs (IL-2, IL-15, IL-18) treatment on comparison MCF7 and NK cell (1:5, 1:2, 1:1, 2:1), different capital letters in the same row (among ratio MCF7 and NK cells) in each ILs concentrations.
}

\section{Discussion}

Induction using ILs (IL-2, IL-15, and IL-18) in NK cells showed that ILs increased activating receptors in NK-92 cells, namely NKG2D/CD334, CD158d, and CD107. This result was in line with previous research that metastatic melanoma (MM) patients exhibited decreased CD161 and NKG2D ${ }^{24}$. The expression of the activating NK cell receptors was significantly decreased in acute myeloid leukemia (AML) patients compared to healthy donors ${ }^{25}$. The biological functions of NK cells are tightly regulated during their interaction with cytokines such as IL-12, IL-15, and IL-18, and the consequences of this interaction are manifested in NK cells ${ }^{26}$. NK cells treated with IL-15 up-regulated the expression of NK receptors, including Nkp30, Nkp46, NKG2C, and NKG2D ${ }^{25}$. This up-regulation is associated with a concomitant increase in the NK cell activity ${ }^{27}$. Human NK cell memory-like responses have been directly demonstrated in vitro following cytokine activation with IL-12, IL-15, and IL-18. A brief (16-hour) pre-activation with IL-12, IL-15, and IL-18, followed by rest in vitro for 1-6 weeks, resulted in enhanced functionality, including IFN- $\gamma$ production following re-stimulation with cytokines, or exposure to leukemia targets ${ }^{28,29}$. IL-2, IL-12, IL-15 and IL-18, applied systemically and for ex vivo activation and expansion of NK cells, have improved NK cell antitumor activity by increasing the expression of NK cell activating receptors and by inducing cytotoxic effector molecules ${ }^{30}$. IL-2 significantly increased KIR2DL1, KIR2DL2, and KIR3DL2 receptors on their surface by $30 \%$ vs. $22 \%, 37 \%$ vs. $30 \%$, and $24 \%$ vs. $14 \%$, respectively ${ }^{31}$. IL-12 alone or in combination with IL-18 significantly induced NK cell activity and CD107a degranulation marker expression in $\mathrm{MM}^{32}$. Resting NK cells typically express very low or undetectable levels of KIR2DL4 on their cell surfaces. Activation of NK cells with IL-2 and feeder cells resulted in a transient increase in the level of cell surface KIR2DL4 ${ }^{33}$. 
ILs increased NK proliferation, and a longer periodic incubation significantly increased NK viability (Table 1). These data were validated with previous research showing that IL15 efficiently triggered the activation and proliferation of $\mathrm{NK}$ and $\mathrm{CD} 8+\mathrm{T}$ cells ${ }^{34,35}$. NK cell activity is regulated by cytokines such as IL-2, IL-12, IL-15, IL-18 and type I interferons (IFNs) ${ }^{36,37}$. NK cells treated with IL2 (IL2-NK) induced the proliferation of injected NK cells in the lung and increased the overall survival of mice with osteosarcoma lung metastasis ${ }^{38}$. The NK cell expansion has been attempted using cytokines such as IL-2 and IL-15 ${ }^{39}$, which are required for both NK cell maturation and survival ${ }^{40}$. IL-2 is the main cytokine that stimulates NK cell activation and proliferation ${ }^{41}$. NK cells also exhibit memory-like properties, and cytokine-induced memory-like (CIML) NK cells are generated via brief pre-activation with IL-12, IL-15, and IL-18 and later exhibited enhanced functionality upon re-stimulation ${ }^{42}$.

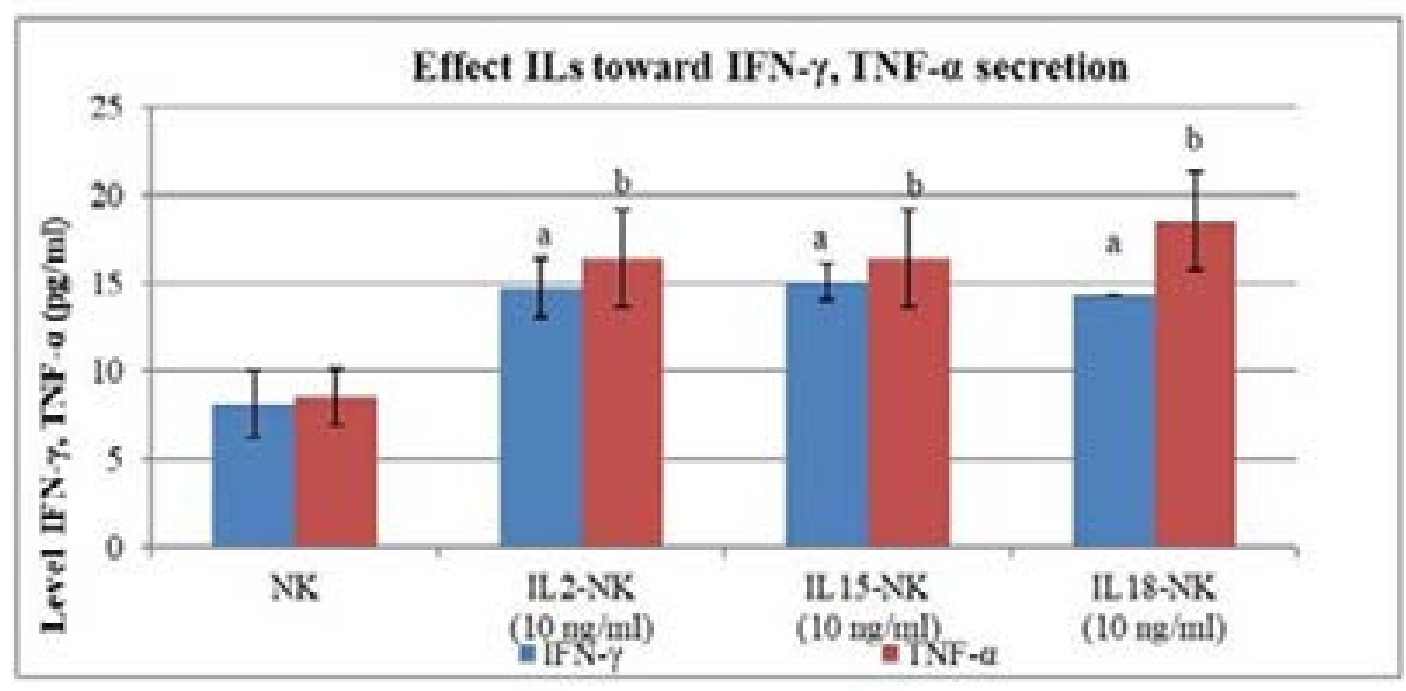

Figure 2. Effect of ILs (IL-2, IL-15, and IL-18) toward IFN- $\gamma$ and TNF- $\alpha$ secretion by NK cells.

\begin{abstract}
*The data are presented as histogram among treatment, this research was conducted in triplicate for each treatment, NK cells were induced ILs $10 \mathrm{ng} / \mathrm{ml}$, incubation for $24 \mathrm{~h}$, symbol (a) present significant differences among inducer (IL-2 $10 \mathrm{ng} / \mathrm{ml}$, IL-15 $10 \mathrm{ng} / \mathrm{ml}$, IL-18 $10 \mathrm{ng} / \mathrm{ml}$ ) compared to control (non-induced NK cells) toward secretion of IFN- $\gamma$, symbol (b) present significant differences among inducer (IL-2 $10 \mathrm{ng} / \mathrm{ml}$, IL-15 $10 \mathrm{ng} / \mathrm{ml}$, IL-18 $10 \mathrm{ng} / \mathrm{ml}$ ) compared to control (noninduced NK cells) toward secretion oTNF- $\alpha$.
\end{abstract}

Interleukin activation of NK cells increased the proliferation and number of NK cells, and longer incubation of NK cells further enhanced proliferation. This result was validated with previous research showing that aerosol IL-2 augments the efficiency of NK cell therapy. Aerosol IL-2 increased organ-specific migration and NK cell expansion in the lung, the number of NK cells in the individual tumor nodules, and tumor cell killing ${ }^{43}$. Aerosol IL-2 increases lung NK cell numbers by stimulating local NK cell proliferation. Aerosol IL2's effect on NK cell proliferation in organ-specific, which makes it ideal for the specific targeting of lung metastasis ${ }^{38,43}$. In vitro studies with IL-2 to support proliferation and in vivo adoptive transfers into murine cytomegalovirus-infected mice demonstrated that NK cell proliferation in- creased $^{44}$. Interleukin 15 (IL-15) promotes the survival of NK cells by preventing apoptosis. IL-15 suppressed apoptosis by limiting Bim expression through the kinases Erk1 and Erk2 and mechanisms dependent on the transcription factor Foxo3a, while promoting expression of Mcl-1, which was necessary and sufficient for the survival of NK cells ${ }^{45}$. NK cells are dramatically reduced in patient carrying mutations, IL-15 may regulate human NK cell development ${ }^{46,47}$, and human IL15 (hIL15) induces survival and proliferation of mouse NK cells ${ }^{48}$. IL-18 promotes NK cell proliferation and activation, alleviating IL18-induced FasL expression and activation of Fas-mediated death signaling and increasing anti-apoptosis molecules $(\mathrm{Bcl}-\mathrm{XL})^{49}$. 
Interleukins (IL2, IL15, and IL18) triggered cytokine (IFN- $\gamma$ and TNF- $\alpha$ ) secretion by NK cells. This result was supported by previous research demonstrating that NK cells can be activated by various stimuli, including cytokines such as IL-2, IL-12, IL-15, and IL-18 ${ }^{50}$. Upon cytokine stimulation, NK cells become LAK cells that proliferate, produce cytokines, and up regulate effector molecules such as adhesion molecules, NKp44, PRF, Gzm, Fas ligand (FasL), and TNF-related apoptosis-inducing ligand (TRAIL) ${ }^{51,52}$. Other factors, such as TNF- $\alpha$, IL-1, IL-2, IL-15 and CD28, serve as co-stimulatory factors, enhancing IFN- $\gamma$ production by NK cells, as well as NK cell proliferation and cytotoxicity ${ }^{53,54}$. IL-12 and IL-18 stimulate NK cell lines, increasing the secretion of IFN- $\gamma^{55}$. IL-12 and IL-18 are critical regulators that activate NK cells via the production of cytokines and direct lysis of target cells ${ }^{56}$. Two of the primary cytokines released by activated NK cells are IFN- $\gamma$ and TNF- $\alpha^{57}$. Activated NK cells are potent producers of numerous cytokines, including IFN- $\gamma$, TNF- $\alpha$ and numerous chemokines ${ }^{56}$.

Co-cultured BC cells (MCF7) and activated NK cells released higher levels of IFN- $\gamma, \mathrm{TNF}-\alpha, \mathrm{PRF} 1$, and GzmB compared to non-induced NK cells. Interleukins (IL-2, IL-15, and IL-18) increased the secretion of IFN- $\gamma$, TNF- $\alpha$, PRF1, and GzmB; this result was in line with previous research that demonstrated an increase in the production of IFN- $\gamma$ and TNF- $\alpha$ in CD107a of co-cultured NK-92 cells with cancer cells (HeLa, SiHa, and $\mathrm{C}-33 \mathrm{~A})$ pre-treated with the antitumor HO-1 inhibitor (SnPP). Antitumor agents increased IFN- $\gamma$ and TNF- $\alpha$ in co-cultured NK cells and cancer cells 19. Expression of apoptosis-related proteins such as cleaved caspase- 3 and Bax was increased in cancer cells co-cultured with NK-92 cells ${ }^{20}$. NK cells kill cancer cells by the release of cytoplasmic granules that contain a number of proteins, such as PRF1 and Gzm, which lyse target cells ${ }^{20}$. NK cells release the membrane-disrupting protein, PRF1, and proteolytic serine proteases, Gzm, from secretory granules ${ }^{57}$. The secretory pathways in NK cells ultimately regulate the separate lytic and regulatory capacity of these cells at the frontline of antitumor responses ${ }^{58}$. When K562 target cells and NK cells were co-cultured at ratios of $5: 1$ or $1: 1$, after $60 \mathrm{~min}$, NK cells produced the cytokines IFN- $\gamma$ and TNF- $\alpha^{58}$.

NK cells have anticancer potency, and higher NK cell numbers significantly increased cytotoxic activity (Table
3). These data were verified by previous studies showing that these cells are major effector cells of innate immunity and are generally thought to play a fundamental role in antitumor responses ${ }^{8,59}$. NK cells control tumor growth and metastasis diffusion in vivo ${ }^{50}$. There are low NK cell numbers in tumors due to their inefficient homing into malignant tissues ${ }^{8}$. Decreasing NK cell numbers are observed in $\mathrm{PB}$ of cancer patients; therefore, NK cells decrease in tumor infiltrate. The activity and numbers of NK cells need to be enhanced for better efficacy ${ }^{60}$. NK cell infiltration in solid tumors was associated with a better prognosis ${ }^{61}$. NK cells need to be isolated and expanded in sufficient numbers for them to act as effector cells ${ }^{60}$. The comparison of effector and tumor determined NK cell cytotoxicity. A previous study showed that the lowest ratio (1.25:1) of effector and cervical epidermoid carcinoma (CaSki), effector and grade II, human cervix squamous cell carcinoma $(\mathrm{SiHa})$ resulted in the highest viable cell target, while the highest ratio (20:1) resulted in the lowest viability or highest inhibition of target cells ${ }^{62}$. In mice lacking IL-12 and IL-18 cytokines, the cytolytic activity of the NK cells is further impaired, indicating that the cytolytic activity of NK cells is synergized by IL-12 and IL-18 in vivo ${ }^{19}$. The NK cells kill cancer cells through at least three mechanisms. NK cells can use the PRF/ Gzm-containing granule exocytosis pathway, the nitric oxide (NO) pathway and the death receptor-ligand pathway. The PRF1/Gzm pathway is the principle pathway by which NK cells kill cancer cells ${ }^{63}$.

\section{Conclusion}

IL-2, IL-15, and IL-18 improved activating receptors and proliferation of NK cells. IL-induced NK cells increased TNF- $\alpha$, IFN- $\gamma$, PRF1, and GzmB secretion and cytotoxic activity on $\mathrm{BC}$ cells. High $\mathrm{NK}$ cell numbers increased $\mathrm{BC}$ cell growth inhibition.

\section{Acknowledgments}

This study was supported by the Grants-in-Aid from Penelitian Dasar Unggulan Perguruan Tinggi (20182020) and Bantuan Seminar Luar Negeri 2018, the Ministry of Research, Technology and Higher Education of the Republic of Indonesia. The authors like to thank to Yukko Arinta, Annisa Amalia, Rismawati Laila Q, Fajar Sukma Perdana, Annisa Arlisyah, Jenifer Kiem Aviani and Ika Adhani Sholihah from Biomolecular and Biomedical Research Center, Aretha Medika Utama, Bandung, West Java, Indonesia for their technical assistants. 


\section{Conflict of interest}

None.

\section{References}

1. Tirona MT, Sehgal R, Ballester O. Prevention of breast cancer (part I): epidemiology, risk factors, and risk assessment tools. Cancer Invest. 2010; 28: 743-750.

2. Kimman M, Norman R, Jan S, Kingston D, Woodward M. The burden of cancer in member countries of the Association of Southeast Asian Nations (ASEAN). Asian Pac J Cancer Prev. 2012; 13: 411-421.

3. Joyce JA, Pollard JW. Microenvironmental regulation of metastasis. Nat Rev Cancer. 2009; 9: 239-252.

4. Kute TE, Savage L, Stehle JR, Kim-Shapiro JW, Blanks MJ, Wood J, et al. Breast tumor cells isolated from in vitro resistance to trastuzumab remain sensitive to trastuzumab anti-tumor effects in vivo and to ADCC killing. Cancer Immunol Immunother. 2009; 58: 1887-1896. 5. Smyth MJ, Dunn GP, Screiber RD. Cancer immunosurveillance and immunoediting: the roles of immunity in suppressing tumor development and shaping tumor immunogenicity. Adv Immunol. 2006; 90: 1-50.

6. Shankaran V, Ikeda H, Bruce AT, White JM, Swanson PE, Old LJ, et al. IFN-gamma and lymphocytes prevent primary tumor development and shape tumor immunogenicity. Nature. 2001; 410: 1107-1111.

7. Dewan MZ, Takada M, Terunuma H, Deng X, Ahmed S, Yamamoto N, et al. Natural killer activity of peripheralblood mononuclear cells in breast cancer patients. Biomed Pharmacother. 2009; 63: 703-706.

8. Levy EM, Roberti MP, Mordoh J. Natural Killer cells in human cancer: from biological functions to clinical applications. J Biomed Biotechnolog. 2011; 2011: 1-11.

9. Hwang YJ, Kim J, Park DS, Hwang KA. Study on the immunomodulation effect of isodon japonicus extract via splenocyte function and nk anti-tumor activity. Int J Mol Sci. 2012; 13: 4880-4888.

10. Esendagli G, Bruderek K Goldmann T, Busche A, Branscheid D, Vollmer E, et al. Malignant and non-malignant lung tissue areas are differentially populated by natural killer cells and regulatory $\mathrm{T}$ cells in non-small cell lung cancer. Lung Cancer. 2008; 59: 32-40.

11. Albertsson PA, Basse PH, Hokland M, Goldfarb RH, Nagelkerke JF, Nanmark U, et al. NK cells and the tumour microenvironment: implications for NK-cell function and anti-tumour activity. Trends Immunol. 2003; 24: 603-609.

12. James AM, Cohen AD, Campbell KS. Combination immune therapies to enhance anti-tumor responses by NK cells. Frontiers Immunol. 2013; 4: 1-12.
13. Cheng M, Chen Y, Xiao W, Sun R, Tain Z. NK cellbased immunotherapy for malignant diseases. Cell Mol Immunol. 2002; 10: 230-252.

14. Curnis F, Sacchi A, Borgna L, Magni F, Gasparri A, Corti A. Enhancement of tumor necrosis factor $\alpha$ antitumor immunotherapeutic properties by targeted delivery to aminopeptidase N (CD13). Nat Biotechnol. 2000; 18: 1185-1190.

15. Morris MA, Ley K. Trafficking of natural killer cells. Curr Mol Med. 2004; 4: 431-438.

16. Rosenberg SA. IL-2: the first effective immunotherapy for human cancer. J Immunol. 2014; 12:5451-5458.

17. Cheng M, Chen Y, Xiao W, Sun R, Tian Z. NK cellbased immunotherapy for malignant diseases. Cellular Mol Immunol. 2013; 10: 230-252.

18. Kelly JM, Darcy PK, Markby JL, Godfrey DI, Takeda $\mathrm{K}$, Yagita $\mathrm{H}$, et al. Induction of tumor-specific $\mathrm{T}$ cell memory by NK cell-mediated tumor rejection. Nat Immunol. 2003; 3: 83-90.

19. Gomez-Lomeli P, Braco-Cuellar A, Hernandez-Florez G, Jave-Suarez LF, Aguillar-Lemaroy A, Lerma-Diaz JM, et al. Increase of IFN- $\gamma$ and TNF- $\alpha$ production in CD107a + NK-92 cells co-cultured with cervical cancer cell lines pre-treated with the HO-1 inhibitor. Cancer Cell Int. 2014; 14: 100.

20. Park MH, Song MJ, Cho MC, Moon DC, Yoon DY, Han SB, et al. Interleukin-32 enhances cytotoxic effect of natural killer cells to cancer cells via activation of death receptor 3. Immunol. 2012; 14: 63-72.

21. Widowati W, Murti H, Jasaputra DK, Sumitro SB, Fauziah N, Maesaroh M, et al. Selective cytotoxic potential of IFN- $\gamma$ and TNF- $\alpha$ on breast cancer cell lines (T47D and MCF7). Asian J Cell Biolog. 2016; 11: 1-12.

22. Parihar R, Dierksheide J, Hu Y. IL-12 enhances the natural killer cell cytokine response to Ab-coated tumor cells. J Clin Invest. 2002; 110: 983-992.

23. Lu YR, Yuan Y, Wang XJ, Wei LL, Chen YN, Cong $\mathrm{C}$, et al. The growth inhibitory effect of mesenchymal stem cells on tumor cells in vitro and in vivo. Cancer Biol Ther. 2008; 7: 245-251.

24. Konjevic G, Mirjacic Martinovi K, Jurisic V, Babovic N, Spuzic I. Biomarkers of suppressed natural killer (NK) cell function in metastatic melanoma: decreased NKG2D and increased CD158a receptors on CD3CD16+ NK cells. Biomarkers. 2009; 4: 258-270.

25. Szczepanski MJ, Szajnik M, Welsh A, Foon KA, Whiteside TL, Boyiadzis M. Interleukin-15 enhances natural killer cell cytotoxicity in patients with acute myeloid leukemia by upregulating the activating NK cell receptors. Cancer Immunol Immunother. 2010; 59: 73-79. 
26. Zwimer NW, Ziblat A. Regulation of NK cell activation and effector functions by the IL-12 family of cytokines: The case of IL-27. Front Immunol. 2017; 8: 1-7. 27. Boyiadzis M, Memon S, Carson J, Allen K, Szczepanski MJ, Vance BA, et al. Up-regulation of NK cell activating receptors following allogeneic hematopoietic stem cell transplantation under a lymphodepleting reduced intensity regimen is associated with elevated IL15 levels. Biol Blood Marrow Transplant. 2008; 14: 290-300. 28. Romee R, Schneider SE, Leong JW, Chase JM, Keppel CR, Sullivan RP, et al. Cytokine activation induces human memory-like NK cells. Blood. 2012; 120: 47514760

29. Ni J, Miller M, Stojanovic A, Garbi N, Cerwenka A. Sustained effector function of IL-12/15/18- preactivated NK cells against established tumors. J Exp Med. 2012; 209: 2351-2365.

30. Konjevic G, Vuletic A, Martinovic KM. Natural killer cell receptors: alterations and therapeutic targeting in malignancies. Immunol Res. 2016; 64: 25-35.

31. Chrul S, Palkowska E, Szadkowska A, Bodalski J. Influence of interleukin IL-2 and IL-12 + IL-18 on surface expression of immunoglobulin-like receptors KIR2DL1, KIR2DL2, and KIR3DL2 in natural killer cells. Mediators Inflamm. 2006; 2006: 46957.

32. Mirjačić Martinović K, Babović N, Džodić R, Jurišić V, Matković S, Konjević G. Favorable in vitro effects of combined IL-12 and IL-18 treatment on NK cell cytotoxicity and CD25 receptor expression in metastatic melanoma patients. J Transl Med. 2015; 13: 1-14.

33. Rajagopalan S, Bryceson YT, Kuppusamy SP, Geraghty DE, Van Der Meer A, Joosten I, et al. Activation of NK cells by an endocytosed receptor for soluble HLA-G. PLOS Biol. 2006; 4: 70-86.

34. Waldmann TA. The biology of interleukin-2 and interleukin-15: implications for cancer therapy and vaccine design. Nat Rev Immunol. 2006; 6: 595-601.

35. Chen Q, Amaladoss A, Ye W, Liu M, Drummler S, Kong F, et al. Human natural killer cells control Plasmodium falciparum infection by eliminating infected red blood cells. Proc Natl Acad Sci USA. 2014; 111: 1479-1484.

36. Zwimer NW, Domaica CI. Cytokine regulation of natural killer cell effector functions. Biofactors. 2010; 36: 274-328.

37. Domaica CI, Fuertes MB, Uriarte I. Human natural killer cell maturation defect supports in vivo CD56 bright to CD56 dim lineage development. Plos One. 2012; 7: 1-12.

38. Guma SR, Lee DA, Yu L, Gordon N, Hughes D,
Stewart J, et al. Natural Killer cell therapy and aerosol interleukin-2 for the treatment of osteosarcoma lung metastasis. Pediatr Blood Cancer. 2014; 61: 618-626.

39. Carson WE, Fehniger TA, Haldar S, Eckhert K, Lindemann MJ, Lai CF, et al. A potential role for interleukin-15 in the regulation of human natural killer cell survival. J Clin Invest. 1997; 99: 937-43.

40. Cooper MA, Bush JE, Fehniger TA, Vandeusen JB, Waite RE, Liu Y, et al. In vivo evidence for a dependence on interleukin 15 for survival of natural killer cells. Blood. 2002; 100: 3633-3638.

41. Dahlberg CI, Sarhan D, Chrobok M, Duru AD, Alici E. Natural killer cell-based therapies targeting cancer: possible strategies to gain and sustain anti-tumor activity. Front Immunol. 2015; 6: 1-19.

42. Leong JW, Sullivan RP, Fehniger TA. MicroRNA management of NK-cell developmental and functional programs. Eur J Immunol. 2014; 44: 2862-2868.

43. Guma SR, Lee DA, Ling Y, Gordon N, Kleinerman ES. Aerosol interleukin-2 induces Natural Killer cell proliferation in the lung and combination therapy improves the survival of mice with osteosarcoma lung metastasis. Pediatr Blood Cancer. 2014; 61: 1362-1368.

44. Tarrio ML, Lee SH, Fragoso MF, Sun HW, KannoY, O'shea JJ, et al. Proliferation conditions promote intrinsic changes in NK cells for an IL-10 response. $J$ Immunol. 2014; 193: 354-363.

45. Huntington ND, Puthalakath H, Gunn P, Naik E, Michalak, EM, Smyth MJ, et al. Interleukin 15-mediated survival of natural killer cells is determined by interactions among Bim, Noxa and Mcl-1. Nat Immunol. 2007; 8: 856-863.

46. Buckley RH. Molecular defects in human severe combined immunodeficiency and approaches to immune reconstitution. Annu Rev Immunol. 2004; 22: 625655.

47. Gilmour KC, Fujii H, Cranston T, Kinnon C. Defective expression of the interleukin-2/ interleukin-15 receptor beta subunit leads to a natural killer cell-defi cient form of severe combined immunodefi ciency. Blood. 2001; 98: 877-879.

48. Huntington ND, Legrand N, Alves NL, Jaron B, Weijer K, Plet A, et al. IL-15 trans-presentation promotes human NK cell development and differentiation in vivo. J Exp Med. 2009; 206: 25-34.

49. Huang Y, Lei Y, Zhang H, Dayton A. Role of interleukin-18 in human natural killer cell is associated with interleukin-2. Mol Immunol. 2010; 47: 2604-2610.

50. Zamai L, Ponti C, Mirandola P, Gobbi G, Papa S, Galeotti L, et al. NK cells and cancer. J Immunol. 2007; 178: 4011-4016. 
51. Moretta L, Bottino C, Pende D, Vitale M, Mingari MC, Moretta A. Different checkpoints in human NKcell activation. Trends Immunol. 2004; 25: 670-676.

52. Hunter CA, Timans J, Pisacane P, Menon S, Cai G, Walker W, et al. Comparison of the effects of interleukin-1 alpha, interleukin-1 beta and interferon-gamma-inducing factor on the production of interferon-gamma by natural killer. Eur J Immunol. 1997; 27: 2787-2792.

53. Hunter CA, Gabriel KE, Radzanowski T, Neyer LE, Remington JS. Type I interferons enhance production of IFN-gamma by NK cells. Immunol Lett. 1997; 59: 1-5 54. Cui R, Rekasi H, Hepner-Schefczyk M, Fessmann K, Petri RM, Bruderek K, et al. Human mesenchymal stromal/stem cells acquire immunostimulatory capacity upon cross-talk with natural killer cells and might improve the NK cell function of immunocompromised patients. Stem Cell Res Ther. 2016; 7: 1-13.

55. Wang R, Jaw JJ, Stutzman NC, Zou Z, Sun PD. Natural killer cell-produced IFN- $\gamma$ and $\mathrm{TNF}-\alpha$ induce target cell cytolysis through up-regulation of ICAM-1. J Leukoc Biol. 2012; 91: 299-309.

56. Vivier E, Raulet DH, Moretta A, Caligiuri MA, Zitvogel L, Lanier LL, et al. Innate or adaptive immunity? The example of natural killer cells. Sci. 2011; 331: 44-49. 57. Trapani JA, \& Smyth MJ. Functional significance of the perforin/granzyme cell death pathway. Nat Rev Immunol. 2002; 2: 735-747.

58. Reefman E, Kay JG, Wood SM, Offenhäuser C, Brown DL, Roy S, et al. Cytokine secretion is distinct from secretion of cytotoxic granules in NK cells. J Immunol. 2010; 184: 4852-4862.

59. Spaggiari GM, Capobianco A, Abdelrazik H, Becchetti F, Mingarii MC, Moretta L. Mesenchymal stem cells inhibit natural killer-cell proliferation, cytotoxicity, and cytokine production: role of indoleamine 2,3-dioxygenase and prostaglandin E2. Blood. 2008; 111: $1327-$ 1333.

60. Mandal A, Viswanathan C. Natural killer cells: in health and disease. Hematol Oncol Stem Cell Ther. 2002; 8: 23-28.

61. Villegas FR, Coca S, Villarrubia VG, Jimenez R, Chillón MJ, Jareño J, et al. Prognostic significance of tumor infiltrating natural killer cells subset CD57 in patients with squamous cell lung cancer. Lung Cancer. 2002; 35: 23-28.

62. Giannattasio A, Weil S, Kloess S, Ansari N, Stelzer $\mathrm{EH}$, Cerwenka A, et al. Cytotoxicity and infiltration of human NK cells in in vivo-like tumor spheroids. BMC Cancer. 2002; 15: 850-861.

63. Smyth MJ, Hayakawa Y, Takeda K, Yagita H. New aspects of natural-killer-cell surveillance and therapy of cancer. Nat Rev Cancer. 2002; 2: 850-861. 